\title{
Collaborative Governance in the Management of Natural Tourism to Increase the Village's Original Income in the Sawang Sub-district
}

\author{
Ahmad Yani ${ }^{1}$, Jumadil Saputra ${ }^{2}$, Zikri Muhammad ${ }^{2}$, Aiyub ${ }^{1,}$ Nazaruddin ${ }^{1,}$ \\ Ti Aisyah ${ }^{1,}$ Cut Lia Musfira ${ }^{3}$ Osea Petege ${ }^{3}$, Rahmat $^{3}$, Laina Miska ${ }^{3}$ \\ ${ }^{1 *}$ Lecturers at Public Administration Departement, Faculty of Sosial and Political Sciences, \\ Universitas Malikussaleh, Lhokseumawe, Indonesia \\ ${ }^{2}$ Faculty of Business, Economics, and Social Development (FBESD), Universiti Malaysia Terengganu, \\ Terengganu, Malaysia \\ ${ }^{3}$ Students at Public Administration Departement, Faculty of Sosial and Political Sciences, Universitas \\ Malikussaleh, Lhokseumawe, Indonesia
}

Email :ahmadyani@unimal.ac.id

\begin{abstract}
Collaborative governance is a joint initiative that is committed to achieving and equalizing the vission and mission in one common goal. Done together in realizing the development and management of natural tourism in North Aceh District,the collaborative process in the management and development of natural Sawang in increasing village income did not go according to plan because there were parties whose charismatic influence did not allow for the development and management of the Sawang nature.This study uses Ansell and Gas theory they are face to face dialogue,trust building, commitment processes, share understanding,intermediate outcomes,this research will produce a new model in tourism development and management.
\end{abstract}

Keywords: collaborative governance, management, original village income

\section{INTRODUCTION}

Collaboration is understood as collaboration between actors, between organizations or between institutions in order to achieve goals that cannot be achieved or carried out independently. collaboration indicators have the same vision and mission, have the same ideas, have the same level of education, have the same effect. It can be concluded that collaborative governance is an institutional system that responds to various public problems that arise in society that involve many actors both from the government and interest groups in the formulation process and implemented to achieve goals and be able to solve common problems. The tourism sector has become a mainstay industry in many regions that is able to give the income, as well as Sawang District in 
developing and managing natural tourist as village income, so that it is able to market many natural tourism potentials in Sawang.

\subsection{Research Problem}

The collaborative process of the government does not run optimally in the management of natural tourism to increase Gampong's income in Sawang sub-district and there are many obstacles in collaborative government

\subsection{Definition of Collaborative Government}

Ansell and Gash explained that Collaborative Governance is a regulation of government where one or more public institutions directly involving non-government stakeholders in taking of formal collective decision, oriented to consensus, deliberative which aims to make and Implement public policy and manage programs or public assets

\subsection{The Process of a Collaboration}

The process of a collaboration is carried out in several stages. A collaboration model stage is important to consider as a strategy in the management aspect of a public affair. Although collaborative processes are difficult to carry out because the characteristics of each stakeholder are different from one another. Ansell and Grash in Ranggi, A.F (2016: 558 - 561)

\section{GOVERNMENT COLLABORATIVE IMPLEMENTATION PROCESS}

collaboration in the mean of process where the collaboration process that occurs includes, direct meetings, build trust, commitment or agreement, mutual understanding and the final result.But, in this study the researchers limit and there are only two indicators that will be see, namely direct meetings or can be interpreted as dialogue in determining the form of collaboration and commitment in the collaborative governance process of natural tourism management in North Aceh District, Sawang Sub-district

\section{RESEARCH METHODS}

The method is used to deepen this research is descriptive with qualitative analysis, to achieve the general description of Collaborative Governance in The Management of Natural Tourism to Increase the Village's Original Income In The Sawang Sub-district.

\section{DISCUSSION}

\subsection{Face to face Dialogue}

At this stage, meetings between stakeholders such as local governments, village governments and communities are held informally such as brainstorming meetings, meetings and information sharing, including discussions on opinion review, at this stage all parties come together to review the policies to be made. and that will be mutually agreed upon.

A face-to-face meeting held by Sawang Subdistrict with influential elements in Sawang Sub-district.According to the Sub-district's opinion that the development and management 
of sawang natural tourism we submit to the village party, meeting between various parties in one location and at the same time so that dialogue occurs Directly or interactively, this does not result in an agreement because influential parties in Sawang Sub-district are of the opinion that natural tourism will cause negative things and no one can be held responsible.

Sawang Subdistrict has done some of these things, such as calling several Geuchik Gampong around natural tourism and involving other than Keuchik Gampong also involving business or private actors and the local community to discuss interests in that tourism management in the future,

A follow-up meeting held by the Sawang Subdistrict which was held in the hall of the Sawang sub-district discussed the continuation of the development and management of natural tourism in Sawang to increase village income. This meeting also did not result in mutual agreement.

\subsection{Commitment to Proses}

Commitment to Process is a commitment or agreement to doing a certain process in order to achieve the desired common goal. Sharing commitment means that they depend on each other to solve problems and solutions, that this process is a common property, and is open to mutual benefits.

There is no agreement in the management of sawang natural tourism in increasing gampong's income, the commitment process does not occur, this results in the implementation of natural sawang tourism management being neglected, sawang natural tourism is only visited and enjoyed by the local community and does not generate gampong's income, there is not yet agreement and cannot involve yet the local governments so that they have not been able yet to assist in the construction of infrastructure such as mushalla, toilets and foot paths.

Collaborative governance is generally created to encourage action or goals that cannot be achieved by either party alone, to be effective it must be able to provide a new mechanism for collective action, it is determined by how the cooperation of the stakeholders as needed to achieve the specified results.

\section{CONCLUSION}

Collaborative mutually agreed failed so that direct meetings and commitments in the process do not run. It is better if policies are made that can coordinate all parties so that collaboration can run smoothly and achieve common goals. The trust of each party is also very needed. The government should contribute to gampong's income sources so that collaboration in managing natural tourism in North Aceh District can run optimally. 


\section{REFERENCES}

Dwiyanto, A. 2011. Manajemen Pelayanan Publik: Peduli, Inklusif, dan Kolaboratif. Yogyakarta: Gadjah Mada University Press.

Heriawan, R. 2004. Peranan dan Dampak Pariwisata Pada Perekonomian. Bogor: Doktoral Insitut Pertanian Bogor.

Lexy J. Moleong. 2005. Metodelogi Penelitian Kualitatif, Bandung: PT. Remaja Rosdakarya.

Spillane, James. 1991. Pengembangan Obyek Wisata. Jakarta: Angkasa

Sugyono, 2008. Metode Penelitian Kualitatif dan Kuantitatif dan R \& D. Bandung: Alfabeta.

Yoeti, O.A. 1997. Perencanaan dan Pengembangan Pariwisata. Jakarta: PT. Pradnya Paramita.

Ranggi, A.F. 2016. Collaborative Governance Dalam Pembangunan Kawasan Perdesaan. Voll. II. No. 1

Tumengkol, A.R. 2015. Kebijakan Pemerintah Dan PertanggungJawabannya Dalam Rangka Good Governance. Jurnal UNSRAT, Voll. III. No. 1 